Original Research Paper

\title{
Ixodid Ticks: Epizootic Status and Methods for Tick Population Size Reduction
}

\author{
Asem Bekbolatovna Myrzhieva, Gulnar Sabyrovna Shabdarbaeva, \\ Gulnar Eldesbaevna Turganbaeva, Aizhan Ilyasovna Balgimbaeva and Asem Serikovna Ibazhanova
}

Kazakh National Agrarian University, Almaty, Kazakhstan

\author{
Article history \\ Received: 10-08-2020 \\ Revised: 12-11-2020 \\ Accepted: 13-11-2020 \\ Corresponding Author: \\ Asem Bekbolatovna Myrzhieva \\ Kazakh National Agrarian \\ University, Almaty, \\ Kazakhstan \\ Email: myrzhieva@mail.ru
}

\begin{abstract}
The paper presents the results of the study of the distribution and seasonal dynamics of ixodid ticks in certain locations and farms of the Almaty, Kyzylorda and Turkestan regions. The results of the study show that the following genera are prevailing in animals and natural biotopes: Hyalomma (H. detritum, H. axiaticum, H. plumbeum, H. scupense and $H$. anatolicum), Ixodes (Ixodes ricinus), Rhipicephalus (Rhipicephalus rossicus) and Dermacentor (Dermacentor marginatus and Dermacentor pictus).
\end{abstract}

Keywords: Abundance Index, Age Dynamics, Ixodid Ticks, Seasonal Dynamics, Species Composition

\section{Introduction}

The work considers the epizootic situation of bloodsucking ixod mites in some Kazakh regions, as well as their seasonal and age dynamics. The predominant species are determined and the degree of mite infection with pathogens of invasive disease is studied.

Blood-sucking ticks are a large group of ectoparasites from the ixodidae family of ticks (Ixodidae), harmful to livestock and people, as they suck blood and are mechanical and biological carriers of vector-borne infectious and parasitic diseases (Chmelař et al., 2016). They are carriers of anthrax, tularemia, pyroplasmosis, babesiosis, anaplasmosis, nuttaliosis, animal theileriosis, CrimeanCongo human hemorrhagic fever, taiga tick-borne human encephalitis and others (Ostfeld and Brunner, 2015; Ogden and Lindsay, 2016; Cull et al., 2018).

Among arthropod vectors of disease, ticks transmit the most diverse array of infectious agents and ticks are the most important arthropod vectors, globally, of pathogens to animals and domestic animals (Pfäffle et al., 2013).

Of the 70 species of ixodid ticks found in Kazakhstan, 23 species are carriers of 18 species of pathogens of animal pyroplasmidoses (Shabdarbaeva et al., 2012). This leads to the challenging epizootic status of pyroplasmidoses, which manifests itself in the formation of various types of foci, the classification of which along with the mapping of the spread of pathogens and their carriers in different regions would serve as the basis for planning and effective implementation of measures to combat them (Shabdarbaeva et al., 2019b). In the epizootic chain of hemoparasitoses, it is important to know the type of tick pathogen transmission: Horizontal (i.e., within the same generation of ticks) or vertical (i.e., to next generations through infected eggs) (Turganbayeva et al., 2018).

Ixodid ticks possess a particular biological feature: Once the blood parasitosis pathogen (for example, pyroplasmosis causative agent, Piroplasma bigeminum) has entered their body, it can be transmitted to up to 60 successive generations, thereby maintaining a permanent focus of the disease in their biotope and animals imported from the hemoparasitosis-free zone might be infected at any time (Shabdarbaeva et al., 2019a).

Although age changes may be different with various animals, every animal has one common general biological feature of age development and biological ageing of the whole organism measured by the animal's biological age (Horak et al., 2018).

Pyroplasmidoses have pronounced seasonality associated with the range and activity of carriers, that is, the disease manifests itself at the locations where carriers infected with a certain type of pathogen and susceptible animals are present (Ismail and McBride, 2017). The season of the disease coincides with the active phase of vector ticks, which are one of the main stages in the epizootic chain: Pathogen - vector - susceptible animal (De la Fuente et al., 2017). This indicates the urgency of developing an integrated tick control method.

The Ixodid tick family includes six genera: Ixodes, Hyalomma, Dermacentor, Boophylus, Rhipicephalus, Haemaphysalis, each of which has from one to twenty species. Each species of ticks lives in areas inherent only to them (biotopes), is active only at a certain time of the 
year and has its own host range and biological characteristics (Mansfield et al., 2017). Measures carried out without an integrated approach and with no regard to the abovementioned characteristics of ticks will not have the desired effect, but rather will cause a deterioration of the environmental status due to the unsystematic use of anti-tick agents.

In recent years, there is a trend of a sharp increase in the tick population caused by changes in economic conditions, the predominance of small private business entities, the absence of planned anti-tick measures and an increase of the uncultivated land area. As a result, new disease foci emerged, exemplified by annual outbreaks of Crimean-Congo hemorrhagic fever with lethal outcome in the southern regions of the Republic of Kazakhstan, the emergence of new foci of hemoparasitoses (for instance, in the Almaty region there was an outbreak of pyroplasmosis with lethal outcome in the Przewalski horses imported to this region) and an outbreak of teileriosis in cattle occurred in 2013 in the environs of Almaty (Akbaev et al., 2008).

Unsystematic use of anti-tick agents with no scientifically based screening causes an environmental problem, as a large number of agents pollute the environment, take a very long time to disintegrate and have cumulative, allergic, teratogenic, embryogenic, thyrotoxic and carcinogenic effects. Their use requires certain restrictions in the use of livestock products, as traces of certain acaricides can be found even in processed products such as oil (butter).

Seventy species of blood-sucking ticks were registered in Kazakhstan. Thirteen species of ixodid ticks were recorded in cattle (Asylkhanov et al., 2015). Tick infection of animals at poorly managed farms reached $100 \%$ and teileriosis (transmitted by ticks) infection rate in these animals amounted to $80 \%$. Parasite load was 15 30 or more ticks per animal. After infecting the host, ticks cause a decrease in the productivity and quality of raw materials. Additionally, they are obligate hematophages and specific biological carriers of dangerous diseases of humans and animals (CrimeanCongo hemorrhagic fever and tick-borne taiga encephalitis in humans, brucellosis, encephalitis, teileriosis, hemosporidial infections and other diseases in animals, plague, typhus and spirochetosis in birds).

Ticks of the genus Hyalomma, which are carriers of the Crimean-Congo hemorrhagic fever, especially Hyalomma asiaticum, Hyalomma anatolicum and Hyalomma plumbeum, have epidemiological significance (Asylkhanov et al., 2015). Ticks retain the pathogen of Crimean-Congo hemorrhagic fever in their body during their whole life (Akhmetova et al., 2019). This disease with a lethal outcome is annually recorded among the population of the southern parts of Kazakhstan. Horse nuttalliosis and cattle anaplasmosis, spread by ticks, are subject to mandatory certification when importing and exporting animals, which emphasizes the urgency of the problem.

The basis of measures aimed at the extermination of ticks was the treatment of farm animals and cattle yards with acaricidal agents (Akhundzhanov et al., 2019).

Organophosphate agents (chlorophos, trichloromethaphos-3, cyodrin and others), carbamate compounds (sevin, dicresil and others) were used at different times for extermination of ticks in animals.

However, the agents used were found to be harmful to animals and cause poisoning of the body. All of these compounds were excreted with milk and remained in the animal's body for a long time (Skosyrskikh and Stolbova, 2017). The disadvantage of most acaricides is the short residual effect of spray materials or emulsions on the skin and hair, which do not exceed six to seven days. After that the risk of tick infection of an animal and, consequently, the risk of the occurrence of blood parasitosis increases. Therefore, farm specialists are forced to carry out weekly treatment of animals with acaricidal agents throughout the summer period, which leads to the heavy expenditure of compounds, increase of cost of animal treatment and expense per unit of livestock production and environmental pollution with acaricide residues. The effectiveness of acaricides with only one active substance is usually not sufficient. Combinations of ingredients with different mechanisms of action are not only effective but also reduce the development of agent resistance (Boiko et al., 2019).

In recent years, several researchers from across the world have carried out epizootological studies, developed therapeutic and prophylactic agents against blood-sucking ticks, tested drugs in acute experiments, studied persistent effects of agents and performed genotyping of ticks (Shabdarbaeva et al., 2019a; Turganbaeva et al., 2016a; 2016b).

For solving the problem of combating ticks, it is important to develop scientifically substantiated integrated measures and search for new agents that have low toxicity for homoithermic animals, are not excreted with milk, are not accumulated in organs and tissues and have a long-lasting persistent (residual) effect against blood-sucking ticks.

Research (mainly epizootological) that determined the species composition of ticks was carried out in Kazakhstan and the countries of CIS (Kazimírová et al., 2017). However, due to anthropogenic factors, species and quantitative composition of ixodids constantly change. Therefore, the study of epizootological features is very important.

One of the most important measures in the comprehensive system of combating pathogens of vectorborne diseases is the extermination of their carriers ixodid ticks. Total devastation, i.e., complete 
extermination of ticks, is an important stage in the system of anti-tick measures. This includes a set of veterinary methods aimed at the destruction of ticks in animals, in livestock buildings and in natural biotopes (pastures).

Preventive measures for vector-borne diseases should be based on the separation of the three main stages, the so-called "Triad": Carrier of the disease pathogen (sick animal) - tick-carrier - healthy (susceptible) animal. The most important method for stages separation is devastation, i.e., the destruction of the 2nd stage: The tick-carrier.

Scientifically substantiated measures of tick control with regard to regional characteristics and tick species composition in the Republic of Kazakhstan are not carried out.

The aim of the research was to develop scientifically substantiated integrated measures of tick control with regard to the species composition of blood-sucking ticks, their seasonal and age dynamics and biological characteristics of tick populations in biotopes of various types and to develop acaricidal agents with a prolonged effect.

\section{Materials and Methods}

The research of the epizootic status of ixodid ticks, seasonal and age dynamics was conducted with Shabdarbaeva Gulnar Sabyrovna, the research manager, in the South Kazakhstan and Almaty regions in autumn 2018 and spring 2019.

Using the "flag" along 32 routes, 2,341 ticks were collected in the Kyzylorda region (South Kazakhstan) and their seasonal dynamics and species composition were determined. In the Zhanakorgan district, studies were carried out in the following locations: "Beymbet" individual farm (Shalkiya village), "Tartogay" farm (Tugines village), "Abasshakh" farm (Tomenaryk village) and "Manap" farm (Birlik village). Studies were carried out during the seasons of peak tick activity in the fall of 2018 and in the spring of 2019. All data were recorded in a workbook according to the requirements and forms of parasitological acarological studies. On the basis of the Department of Biological Safety, the ticks were sorted into pools, five adults in each pool according to their sex, type and developmental phase in a $2 \mathrm{~mL}$ test tube.

By year-round ten-day examination of tick biotopes, we collected and identified tick species, studied the dynamics of tick parasite loads in different species: Hyalomma scupense, Hyalomma anatolicum, Hyalomma plumbeum, Hyalomma asiaticum, Hyalomma detritum, determined preferred hosts and studied the characteristics of tick biotopes in the South Kazakhstan region. We used generally accepted forms of acarological documentation to register tick abundance: A journal for recording the results of animal examination for the presence of ticks and a journal for recording the results of the inspection of premises and pastures for the presence of ticks. Records were kept during three years.

Tick labeling was carried out according to the generally accepted methods: Determination of predominant hosts; collection, storage and identification of species in compliance with the required safety measures were carried out according to the methods described by Pavlovsky E.N., 1959; Blagoveshchensky D.I., 1972; Volskis G.I., 1977; Dubinina 1977, with filling out both front and back sides of the label. Inspection of 746 large animals for tick collection was performed throughout the whole body after fixing them in a trevis or putting them on a leash. Inspection of 620 small animals was performed in basins or cuvettes placed in larger glassware with acaricidal liquid. Examination of natural pastures for the presence of ixodid ticks was carried out using a drag harrow, flag, drill harrow and experimental animal grazing (Turganbaeva et al., 2016a).

Office processing of tick samples and determination of their genus and species were performed using tick identifier tables for the Ixodidae family (Turganbaeva et al., 2016a).

Ten-day and monthly summarized data was arranged in the form of tables and diagrams, plotted on the maps of the region and used as a scientific basis for the development of a scientifically substantiated comprehensive set of health-improving measures against vector-borne diseases of animals and their carriers (Turganbaeva et al., 2016a).

The identification of the preferred host of ixodid ticks was carried out by examination of $10 \%$ of the animals of the entire livestock (1,366 animal species); a survey of the number of ticks and determination of the average number of ticks per animal were determined using the following formula:

$$
B=(K \times 100) \div C
$$

where, $B$ is animal species, $K$ is the number of ticks found on animals of this species and $C$ is the total number of ticks of this species found on animals of all species (Turganbaeva et al., 2016a).

The invasive diseases pathogens infection rate in ticks by regions was studied using incubation of ticks according to the method of N.G. Olsufiev (Turganbaeva et al., 2016a). After that, they were replanted on the bodies of animals (80 rabbits, 540 sheep, 746 cattle) for feeding. When eggs were laid by ticks, conditions were created for the emergence of larvae and, later, nymphs, periodically using a corresponding animal as a feeding source. To detect blood parasites infection in ticks, they were dissected and preparations were made and studied: 
Hemolymph smears according to the method of I.V. Abramova; smears from salivary glands and laid eggs according to the method of A.A. Tsaprun and A.A. Markov (Shabdarbaeva et al., 2019a).

Development of integrated measures to control blood-sucking ticks by establishing animal treatment schemes and rational timing of anti-tick treatments, taking into account epizootological data, biological characteristics of ticks, characteristics of components and the nature of the tick biotope.

\section{Results}

\section{Ixodid Ticks Epizootic Status in the Kyzylorda Region}

Ticks were collected during the autumn months of 2018 from the following animal species: 100 cattle animals, 475 sheep, 385 goats and 75 horses of different ages and breeds.

In autumn, 1,037 ticks were collected and identified. In particular, Hyalomma scupense was recorded in Birlik (the proportion was $19.19 \%)$, Tugines (16.49\%) and Shalkiya (15.53\%). The proportion of Hyalomma anatolicum was $14.46 \%$ in Shalkiya, $13.69 \%$ in Tomenaryk and $11.96 \%$ in Birlik. $42.6 \%$ of all studied ticks were male while females accounted for $57.4 \%$ of the total number (Fig. 1).

Study of the seasonal fluctuations of the abundance of ticks recorded during autumn showed that proportion of $H$. anatolicum in September was $43.99 \%$ of the total number sampled, in October it was $35.55 \%$ and in November it was $19.47 \%$. The proportion of $H$. scupense was $46.22 \%$ in September, $40.90 \%$ in October and $12.88 \%$ in November. It is worth noting that the dynamics of these two tick species were similar, the highest proportion of both species was recorded in September (43.99 and 46.22\%, respectively), then it decreased to 35.55 and $40.90 \%$, respectively, in October and the lowest values were recorded in November: 19.47 and $12.88 \%$, respectively.

The study of the tick parasite load in different animal species in the spring months of 2019 at the same farms of the Zhanakorgan district of the Kyzylorda region showed a sharp increase in the number of ticks attacking animals and the appearance of new tick species in the samples (Fig. 2).

The same ixodid species were recorded in spring as were in autumn, i.e., Hyalomma anatolicum (506 specimens, or $15.62 \%$ of the total number sampled) and Hyalomma scupense (754 specimens, or 23.26\%).

In addition, other species from the Hyalomma genus were identified: $H$. asiaticum (832 specimens, or $25.67 \%$ ), $H$. detritum (602 specimens, or $18.57 \%$ ) and $H$. plumbeum (547 specimens, or $16.88 \%$ ).

Males prevailed in spring samples and amounted to 1,988 , or $61.34 \%$ of the total number sampled; 1,253 (or $38.66 \%$ of all sampled ticks) were female.

The analysis of the seasonal dynamics of ticks sampled in spring shows that the highest peak of abundance in all tick species occurred in April: $H$. anatolicum - 43.28\%, $H$. scupense $-51.33 \%, H$. detritum - $66.61 \%, H$. asiaticum 49.64\% and $H$. plumbeum $-66.54 \%$.

Additionally, the proportion of all registered tick species was also the highest (55.05\%) in April (Fig. 3).

In May, the abundance of ticks was still rather high: H. anatolicum - 37.75\%, H. scupense - $27.05 \%, H$. detritum - $18.61 \%, H$. asiaticum - $36.78 \%$ and $H$. plumbeum - $18.65 \%$. The proportion of all registered tick species in May was $28.23 \%$ (on average) of the total number sampled (Table 1 and Fig. 4).

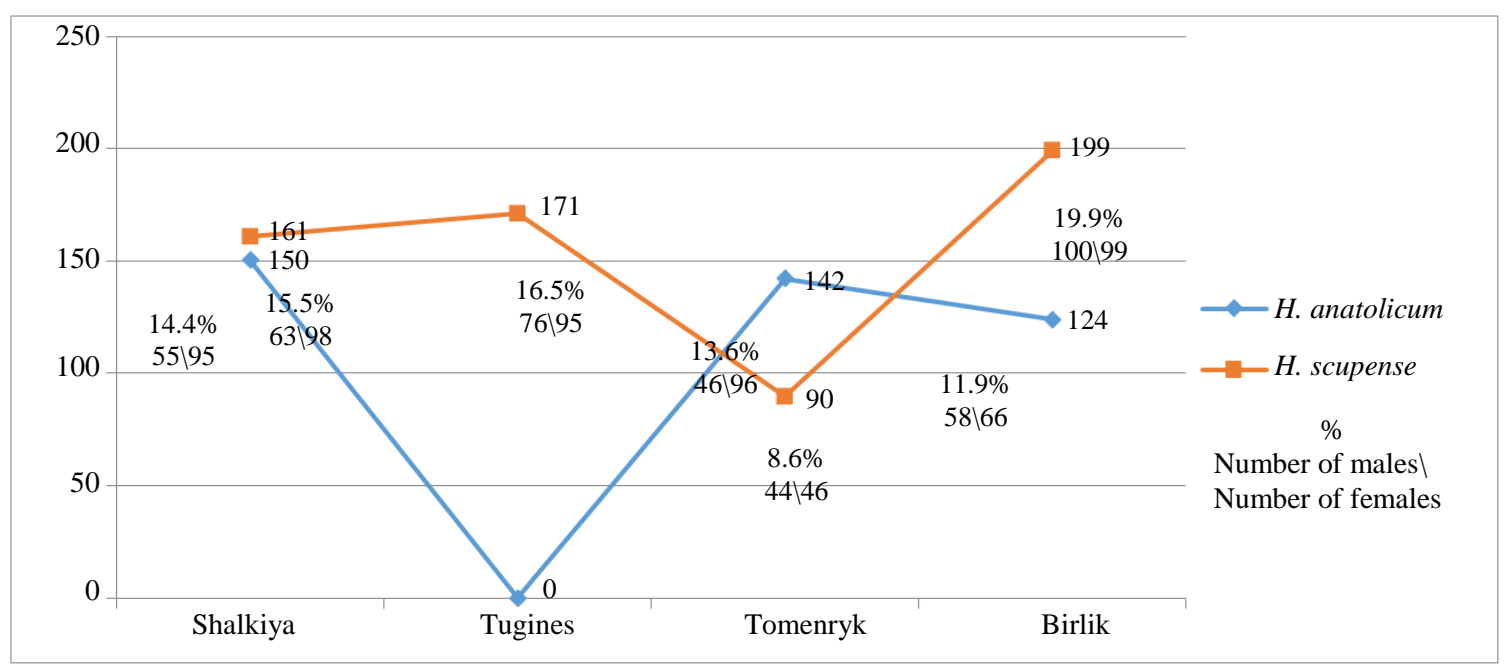

Fig. 1: Ixodid species composition in the Zhanakorgan district of the Kyzylorda region (autumn sampling) 


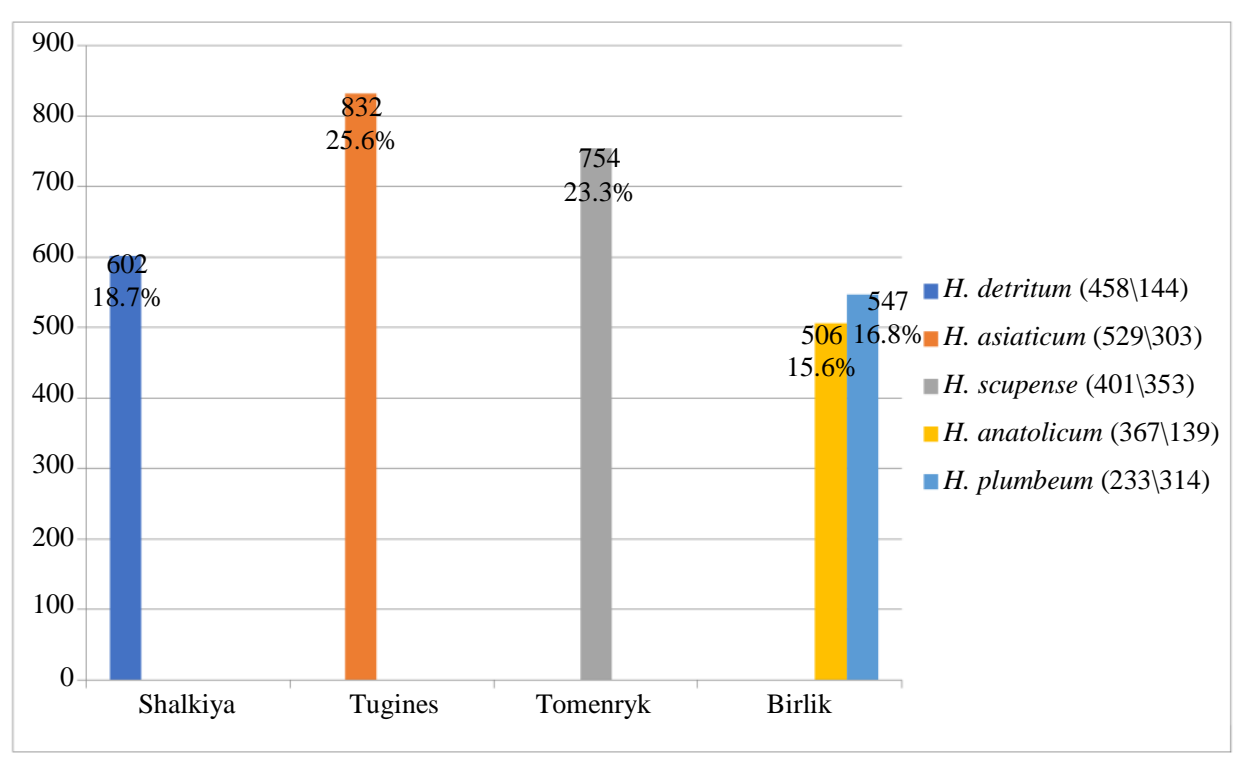

Fig. 2: Ixodid species composition in the Zhanakorgan district of the Kyzylorda region (spring sampling)

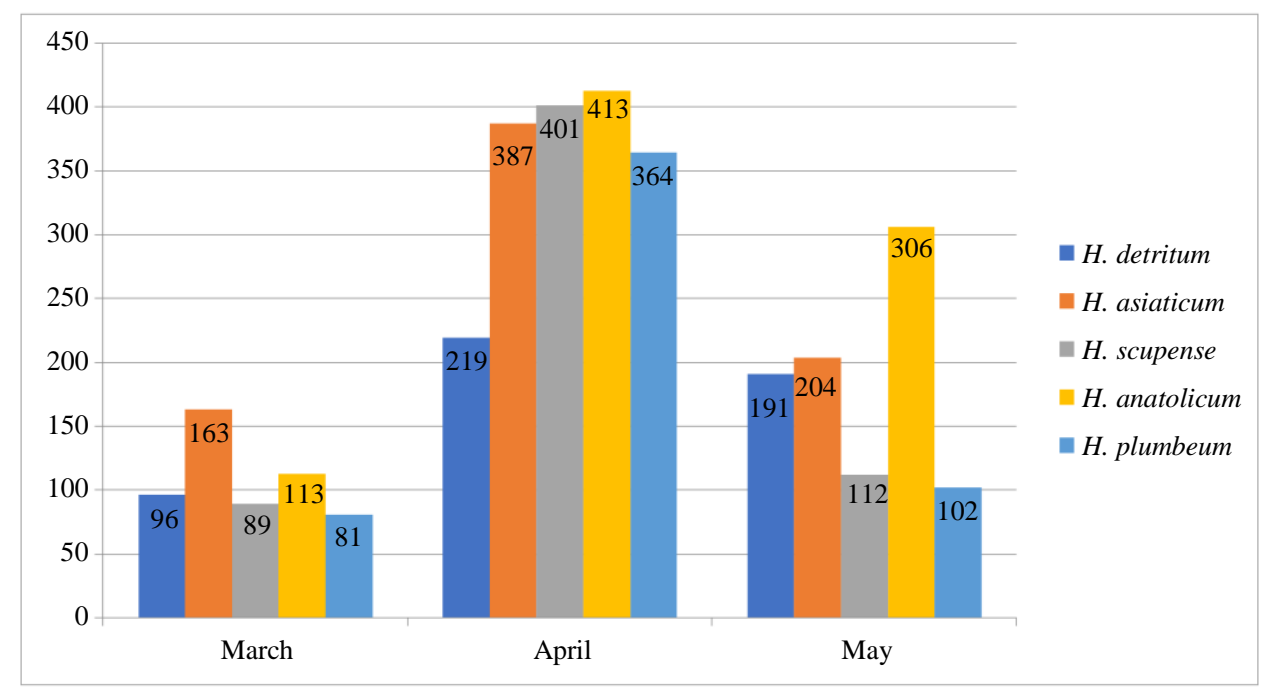

Fig. 3: Seasonal dynamics of tick parasite loads in animals during spring in the Zhanakorgan district of the Kyzylorda region

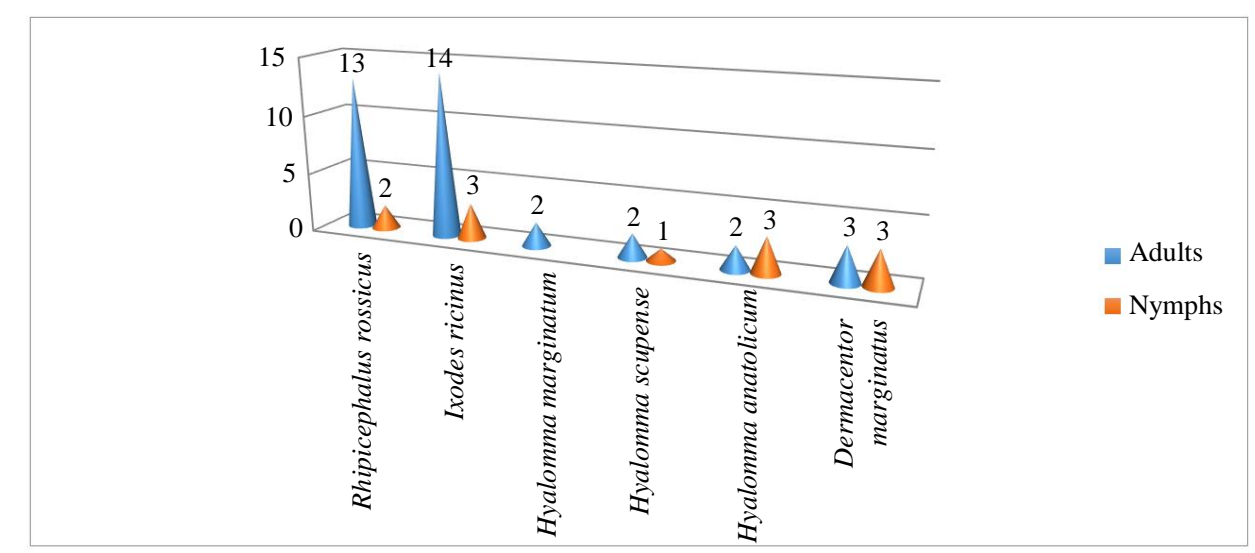

Fig. 4: Tick species composition in the Karasai district of the Almaty region 
Table 1: Tick prevalence in different animal species in Shymkent and its suburbs

\begin{tabular}{|c|c|c|c|c|c|}
\hline \multirow[b]{2}{*}{ No. } & \multirow[b]{2}{*}{ Animal species } & \multirow[b]{2}{*}{$\begin{array}{l}\text { Number of } \\
\text { animals examined }\end{array}$} & \multicolumn{3}{|c|}{ Prevalence } \\
\hline & & & Number & $\%$ & $\begin{array}{l}\text { Abundance } \\
\text { index, ind./anim. }\end{array}$ \\
\hline 1 & Camels & 20 & 1.0 & 5.0 & 15.6 \\
\hline 2 & Horses & 20 & 3.0 & 15.0 & \\
\hline 3 & Cattle & 20 & 8.0 & 40.0 & \\
\hline 4 & Donkeys & 20 & 1.0 & 5.0 & \\
\hline 5 & Dogs & 20 & 3.0 & 15.0 & \\
\hline Total: & 100 & 16 & 16.0 & & \\
\hline
\end{tabular}

The smallest number of ticks was sampled in March: H. anatolicum - $18.97 \%, H$. scupense -- 21.62\%, H. detritum - $14.78 \%, H$. asiaticum - $13.58 \%$ and $H$. plumbeum - $14.82 \%$. The proportion of all registered tick species in March was $16.72 \%$ (on average) of the total number sampled (Fig. 3).

Therefore, two tick species of the genus Hyalomma were constantly recorded in various villages of the Zhanakorgan district of the Kyzylorda region, regardless of the season, in particular, Hyalomma scupense and Hyalomma anatolicum, which were also predominant in abundance.

In the spring, other species from the genus Hyalomma were found along with the abovementioned ones, in particular: $H$. detritum $-18.61 \%, H$. asiaticum $36.78 \%$ and $H$. plumbeum $-18.65 \%$.

In the studied region, the villages with the poorest status were Birlik, Tugines Auylynda and Shalkya, where $H$. scupense ticks predominated in abundance.

The analysis of the seasonal dynamics of the tick parasite load in animals in the Zhanakorgan district showed that the peak parasite load was observed in April, which reached 218 to 413 individuals depending on the tick species.

\section{Ixodid Ticks Epizootic Status in the Almaty Region}

During the study, various cattle animals were examined for the presence of ticks in several districts of the Almaty region, 187 ixodid ticks were sampled. The results are shown in Table 2.

Out of the total number, 139 ticks were adult females (74.4\%) and 33 individuals were adult males (17.6\%). Additionally, we found eleven nymphs (5.9\%) and four larvae $(2.1 \%)$.

The analysis of the species percentage showed that Dermacentor marginatus was predominant: Its proportion was $45.5 \%$ and Dermacentor pictus was the second with a proportion of $33.7 \%$.

Hyalomma plumbeum ticks were also common, their proportion was $12.3 \%$. The single-host Boophilus calcaratus ticks were the rarest, their proportion was $8.5 \%$.

The proportion of females in the total number of the most common Dermacentor marginatus ticks was $81.18 \%$, which was significantly higher than the proportion of males $(23.81 \%)$; the proportion of nymphs was $6.35 \%$ and the proportion of larvae was $2.35 \%$.

The proportion of females in the total number of Dermacentor pictus ticks was $68.25 \%$, the proportion of males was $14.12 \%$, the proportion of nymphs was $2.35 \%$ and the proportion of larvae was $1.59 \%$ (Table 3 ).

The proportion of females in the total number of Hyalomma plumbeum ticks was $69.57 \%$, the proportions of males and nymphs were $13.04 \%$ and the proportion of larvae was $4.35 \%$.

The proportion of females in the total number of Boophilus calcaratus ticks was $68.75 \%$; the proportion of males was $18.75 \%$ and the proportion of nymphs was $12.50 \%$. No larvae of this species were found.

Off all the horses examined in the Karasai district of the Almaty region, 12 had ticks, $(44.4 \%)$. Ticks were found mainly in the area of the udder and groin.

Six tick species from four genera of ixodids were identified in this location (Fig. 4).

Figure 4 show that out of total number (48) of ticks sampled, 36 were adult $(75.00 \%)$ and 12 were nymphs $(25.00 \%)$. The abundance index was low: 3.8 individuals per animal on average.

Therefore, Ixodes ricinus predominates in the studied location (35.41\%) and Rhipicephalus rossicus has the second place $(31.25 \%)$ while findings of ticks of the genus Hyalomma were sporadic (from 4.17 to $10.42 \%)$ and Dermacentor marginatus was also relatively rare $(12.50 \%)$.

\section{Epizootic Situation on Ticks at Certain Locations of the Turkestan Region}

To study the fauna and species composition of the ixodid ticks of the Turkestan region, parasites were collected in three locations: At the village of Kulan in the Shaulder district, in the Tulkibas district and in the city of Shymkent.

Twenty camels, twenty horses, twenty dogs, twenty donkeys and twenty cattle animals, as well as habitats, i.e., tick biotopes, were examined for the presence of ticks in Kulan. The sampling and determination of tick species was carried out according to the abovementioned methods. The results of the study of animals in the region are shown in Table 4. 
Table 2: Tick species composition in Shymkent and its suburbs

\begin{tabular}{|c|c|c|c|c|c|c|c|c|}
\hline \multirow[b]{3}{*}{ No. } & \multirow[b]{3}{*}{ Tick species } & \multirow[b]{3}{*}{ Number } & \multirow[b]{3}{*}{$\%$} & \multicolumn{4}{|l|}{ Stages } & \multirow{3}{*}{$\begin{array}{l}\text { Abundance index, } \\
\text { ind./anim. }\end{array}$} \\
\hline & & & & \multicolumn{2}{|l|}{ Adults } & \multicolumn{2}{|l|}{ Nymphs } & \\
\hline & & & & Number & $\%$ & Number & $\%$ & \\
\hline 1 & Hyalomma scupense & 103 & 41.04 & 98.00 & 95.14 & 5.00 & 4.85 & 15.6 \\
\hline 2 & Hyalomma anatolicum & 95 & 37.85 & 89.00 & 93.68 & 6.00 & 6.32 & \\
\hline 3 & Dermacentor marginatus & 36 & 14.34 & 31.00 & 86.11 & 5.00 & 13.89 & \\
\hline 4 & Dermacentor pictus & 11 & 4.38 & 9.00 & 81.81 & 2.00 & 18.18 & \\
\hline 5 & Ixodes ricinus & 6 & 2.39 & 4.00 & 66.67 & 2.00 & 33.33 & \\
\hline Total: & 251 & 100,0 & 231.00 & 92.03 & 20.00 & 7.97 & & \\
\hline
\end{tabular}

Table 3: Tick species composition in the samples from the Almaty region

\begin{tabular}{|c|c|c|c|c|c|c|c|}
\hline \multirow[b]{2}{*}{ No. } & \multirow[b]{2}{*}{ Tick species } & \multirow[b]{2}{*}{ Total number } & \multicolumn{4}{|l|}{ Stages } & \multirow[b]{2}{*}{$\begin{array}{l}\text { Proportion } \\
\%\end{array}$} \\
\hline & & & $\begin{array}{l}\text { Females } \\
\text { number/\% }\end{array}$ & $\begin{array}{l}\text { Males } \\
\text { number/\% }\end{array}$ & $\begin{array}{l}\text { Nymphs } \\
\text { number/\% }\end{array}$ & $\begin{array}{l}\text { Larvae } \\
\text { number/\% }\end{array}$ & \\
\hline 1 & H. plumbeum & 23 & $16 / 69.57$ & $3 / 13.04$ & $3 / 13.04$ & $1 / 4.35$ & 12.3 \\
\hline 3 & D. pictus & 63 & $43 / 68.25$ & $15 / 23.81$ & $4 / 6.35$ & $1 / 1.59$ & 33.7 \\
\hline 4 & D. marginatus & 85 & $69 / 81.18$ & $12 / 14.12$ & $2 / 2.35$ & $2 / 2.35$ & 45.5 \\
\hline 5 & B. calcaratus & 16 & $11 / 68.75$ & $3 / 18.75$ & $2 / 12.50$ & $-/ 0.0$ & 8.5 \\
\hline Number/\% & $187 / 100.0$ & $139 / 74.4$ & $33 / 17.6$ & $11 / 5.9$ & $4 / 2.1$ & 100.0 & \\
\hline
\end{tabular}

Table 4: Tick prevalence in different animal species in the Kulan village of the Shaulder district of the Turkestan region

\begin{tabular}{|c|c|c|c|c|}
\hline \multirow[b]{2}{*}{ No. } & \multirow[b]{2}{*}{ Animal species } & \multirow[b]{2}{*}{$\begin{array}{l}\text { Number of } \\
\text { animals examined }\end{array}$} & \multicolumn{2}{|c|}{ Prevalence } \\
\hline & & & Number & $\%$ \\
\hline 1 & Camels & 20 & 5.0 & 25.0 \\
\hline 2 & Horses & 20 & 6.0 & 30.0 \\
\hline 3 & Cattle & 20 & 7.0 & 35.0 \\
\hline 4 & Donkeys & 20 & 5.0 & 25.0 \\
\hline 5 & Dogs & 20 & 11.0 & 55.0 \\
\hline Total: & 100 & 34 & 34.0 & \\
\hline
\end{tabular}

Table 5: Tick species composition in the Tulkubas district

\begin{tabular}{|c|c|c|c|c|}
\hline \multirow[b]{2}{*}{ No. } & \multirow[b]{2}{*}{ Animal species } & \multirow[b]{2}{*}{$\begin{array}{l}\text { Number of } \\
\text { animals examined }\end{array}$} & \multicolumn{2}{|c|}{ Prevalence } \\
\hline & & & Number & $\%$ \\
\hline 1 & Camels & 20 & 1.0 & 5.0 \\
\hline 2 & Horses & 20 & 3.0 & 15.0 \\
\hline 3 & Cattle & 20 & 10.0 & 50.0 \\
\hline 4 & Donkeys & 20 & 1.0 & 5.0 \\
\hline 5 & Dogs & 20 & 3.0 & 15.0 \\
\hline Total: & 100 & 18 & 18.0 & \\
\hline
\end{tabular}

The total tick prevalence in animals of different species was 34 out of 100 examined or $34.0 \%$. The highest prevalence was observed in dogs $(55.0 \%)$ and cattle was second $(35.0 \%)$; it was $30.0 \%$ in horses and $25.0 \%$ in other animal species (camels and donkeys). Ticks were found in the auricles and eyelids, in the axillary and inguinal areas, on the udder, on the base and tip of the tail. In total, 403 ticks were sampled from different species of animals in the Tulkubas district. The following species were identified in the samples (Table 5).

In the studied region, 18 out of 100 animals of different species examined (or 18\%) had ticks and the abundance index was 22.3 individuals per animal on average.
Therefore, Hyalomma anatolicum (36.5\%) and Hyalomma scupense (23.8\%) were predominant in the studied locations of the Tulkubas district. Ticks of the genus Dermacentor were second, the proportion of Dermacentor marginatus was $23.2 \%$ and the proportion of Dermacentor pictus was $12.6 \%$. Findings of Ixodes ricinus in this region were sporadic and its proportion was $3.9 \%$ of the total number sampled.

The study of animals in the city of Shymkent and its suburbs showed that the total prevalence in animals was $16.00 \%$, the total number of ticks sampled from animals was 251. The abundance index was 15.6 individuals per animal on average (Table 1). 
The following tick species were identified in the samples from this region (Table 2).

Therefore, the species Hyalomma scupense (41.04\%) and Hyalomma anatolicum $(37.85 \%)$ also prevailed in the studied locations of Shymkent and its suburbs. Ticks of the genus Dermacentor were second, the proportion of Dermacentor marginatus was $14.34 \%$ and the proportion of Dermacentor pictus was $4.38 \%$. Findings of Ixodes ricinus in this region were sporadic and its proportion was $2.39 \%$ of the total number sampled.

Additionally, we studied methods of tick abundance regulation and reduction of their population size. In this regard, several versions of the formulations of antiacaricidal products have been developed and tested, which contain more effective acaricidal and environmentally friendly agents.

There is an insecticide and acaricidal agent containing fipronil, esfenvalerate, citric acid, polyethylene glycol and isopropyl alcohol as a solvent (Smirnov, 2002). However, fipronil does not have a quick contact effect, it is effective only for long-term application and long-term contact with ticks for the manifestation of sufficient acaricidal effect. The acaricidal activity of esfenvalerate is low.

Our aim was to create an insecticide and acaricide, which would be a universal remedy against known skin parasites of mammals, which would be cheap and effective and, at the same time, practical (due to the use of an antioxidant).

This problem was solved by selecting components for the composition that meets the abovementioned requirements. The technical effect is achieved by the fact that the acaricidal agent Ratios of components are the following, wt. \%: Fipronil - 0.05-10.0; esfenvalerate 0.05-0.1; benzyl benzoate - 5.0-40.0; alphacipermetrin 0.01-10.0; metoprene - 0.01-1.0; polyethylene glycol.

Fipronil is an insecticide and acaricide of the phenylpyrazole group, the mechanism of contact action is the blocking of GABA-dependent receptors in arthropods, which impairs the transmission of nerve impulses and leads to paralysis and death of ectoparasites. When applied to the skin, fipronil is localized in the sebaceous glands, without entering the animal's blood, creating the effect of a "reservoir", which provides a long-lasting effect and allows the compound to spread on the surface of the skin and coat. The disadvantage is a delayed action against ectoparasites (after about $24 \mathrm{~h}$ of gradual distribution over the entire surface of the animal's body).

Esfenvalerate is a contact insecticide of a pyrethroid type for controlling a wide range of insect pests, which has destructive, repellent, paralyzing and antifeedant effects.

Benzyl benzoate is toxic to ticks (Šimo et al., 2017). It is an antioxidant, which has effective properties of a preservative, allowing storing the insecticidal and acaricidal product made on the basis of the proposed composition for a long time both in packaging and in use.
Alphacipermetrin has a high acaricidal activity with rapid action, dramatically limits the movement of ticks on the surface of the body and does not accelerate the intrusion of ticks into the animal skin. The disadvantage is relatively high toxicity to animals, rapid excretion from the body and reduction of the contact effect.

Metoprene is an analogue of juvenile hormone, an arthropod growth regulator. Disrupting the synthesis of chitin, it causes anomalies in arthropod development at the stage of an egg and larva and prevents the appearance of mature adult arthropods in animals and in the places where they are kept.

Polyethylene glycol (State Standard 5593) is used as a surfactant.

Thus, the composition of the proposed insecticide contains fipronil and esfenvalerate, the composition additionally contains benzyl benzoate, alfacipermethrin, metoprene and an organic solvent, in particular, polyethylene glycol.

The advantage of the proposed composition is the creation of an insectoacaricide, which is a universal remedy against known mammalian skin parasites, cheap and effective; practical, due to the use of an antioxidant; safe, by reducing the concentration of active substances.

The newly developed product is protected by the Patent of the Republic of Kazakhstan for utility model No. 3346 dated November 7, 2018 (Shabdarbaeva et al., 2018).

\section{Discussion}

The epizootic status for blood-sucking ticks was studied for the first time at certain locations and farms in the Almaty, Kyzylorda and Turkestan regions. As a result of the studies, it was found that the species Ixodes ricinus predominated at the farms and locations in the Almaty region (36.9\%) and Rhipicephalus rossicus was second $(32.6 \%)$; findings of ticks of the genus Hyalomma were sporadic (from 4.3 to 10.8\%) and Dermacentor marginatus was also relatively rare $(13.0 \%)$.

In the Otyrar region, Hyalomma scupense (41.04\%) and Hyalomma anatolicum (37.8\%) were the predominant species. Dermacentor genus was second: The proportion of Dermacentor marginatus was $14.3 \%$ and the proportion of Dermacentor pictus was $4.3 \%$. Findings of Ixodes ricinus were sporadic: $2.3 \%$ of the total number sampled.

In the Tulkubas district, Hyalomma anatolicum (36.4\%) and Hyalomma scupense (23.8\%) were the predominant species. Dermacentor genus was second: the proportion of Dermacentor marginatus was $23.03 \%$ and the proportion of Dermacentor pictus was $12.6 \%$. Findings of Ixodes ricinus in this region were sporadic: $3.9 \%$ of the total number sampled.

A patented insecticidal and acaricidal agent has been developed for the treatment of animals and reduction of 
the ixodid ticks population, the advantage of which is high efficiency and versatility against known skin parasites of mammals, low cost, practicality (due to the use of an antioxidant) and safety (due to the reduction of concentrations of active substances).

\section{Conclusion}

Data on the epizootic situation of different types of ticks will allow improving epidemiological surveillance and preventive measures for tick-borne encephalitis.

\section{Acknowledgment}

The authors would like to express their gratitude to the Kazakh National Agrarian University for the financial support.

\section{Author's Contributions}

All authors contributed equally.

\section{Ethics}

There are no conflicts of interest to declare.

\section{References}

Akbaev, M. S., Vasilevich, F. I., Akbaev, R. M., Vodyanov, A. A., Kosminkov, N. E., Pashkin, P. I., \& Yatusevich, A. I. (2008). Parazitologiya i invazionnye bolezni zhivotnykh [Parasitology and invasive diseases of animals]. Kolos, Moscow. ISBN: 978-5-9532-0441-5. https://www.studentlibrary.ru/book/ISBN97859532 04415.html

Akhmetova, T. D., Myrzhieva, A. B., Balgimbaeva, A. I., \& Shabdarbaeva, G. S. (2019). Issledovanie iksodovykh kleshchei na nalichie kroveparazitov [The study of ixodid ticks for the presence of blood parasites]. Materialy mezhdunarodnoi konferentsii studentov, aspirantov, molodykh uchenykh "Studforum - 2019" [Materials of the international conference of students, post-graduate students and young scientists "Studforum - 2019"], Eurasian Scientific and Industrial Chamber, Moscow. https://scienceforum.ru/2019/article/2018016166

Akhundzhanov, M. R., Shabdarbaeva, G. S., \& Balgimbaeva, A. I. (2019). Iksodofauna plotoyadnykh v Almatinskoi oblasti [Ixodofauna of carnivores of the Almaty region]. Materialy IV Mezhdunarodnoi Studencheskoi Nauchnoi Konferencii Mezhdunarodnogo nauchnogo foruma [Materials of the IV International Student Scientific Conference International Scientific Forum]. Moscow. https://studconf.com/conference/iii/veterinary/sub85/574/
Asylkhanov, D. U., Turganbaeva, G. E., Akhmetzhanova, M., Khusainov, D. M., Shabdarbaeva, G. S., \& Tulepova, G., (2015). Kormlenie i inkubatsiya iksodovykh kleshchei [Feeding and incubation of ixodid ticks]. In: Materialy IV Mezhdunarodnoi konferentsii "Kontseptualnye i prikladnye aspekty nauchnykh issledovanii i obrazovaniya $\mathrm{v}$ oblasti zoologii bespozvonochnykh" [Materials of the IV International Conference "Conceptual and Applied Aspects of scientific research and education in the field of invertebrate zoology], Romanenko, V.N., Yu.V. Maximova, R.T. Baghirov and E.Y. Subbotina, (Eds.), Publishing House of Tomsk State University, Tomsk, pp: 219-222. ISBN: 978-5-94621-534-3.

Boiko, A. A., Myrzhieva, A. B., \& Shabdarbaeva, G. S. (2019). Kleshchi - perenoschiki piroplazmoza sobak [Ticks - carriers of pyroplasmosis in dogs]. Materialy mezhdunarodnoi konferentsii studentov, aspirantov, molodykh uchenykh "Studforum 2019" [Materials of the international conference of students, post-graduate students and young scientists "Studforum - 2019"]. Eurasian Scientific and Industrial Chamber, Moscow. https://scienceforum.ru/2019/article/2018016164

Chmelař, J., Kotál, J., Kopecký, J., Pedra, J. H., \& Kotsyfakis, M. (2016). All for one and one for all on the tick-host battlefield. Trends in parasitology, 32(5), 368-377.

Cull, B., Pietzsch, M. E., Hansford, K. M., Gillingham, E. L., \& Medlock, J. M. (2018). Surveillance of British ticks: An overview of species records, host associations and new records of Ixodes ricinus distribution. Ticks and tickborne diseases, 9(3), 605-614.

De la Fuente, J., Antunes, S., Bonnet, S., Cabezas-Cruz, A., Domingos, A. G., Estrada-Peña, A., ... \& Papa, A. (2017). Tick-pathogen interactions and vector competence: identification of molecular drivers for tick-borne diseases. Frontiers in cellular and infection microbiology, 7, 114.

Horak, I. G., Heyne, H., Williams, R., Gallivan, G. J., Spickett, A. M., Bezuidenhout, J. D., \& EstradaPeña, A. (2018). The ixodid ticks (Acari: Ixodidae) of southern Africa. Springer.

Ismail, N., \& McBride, J. W. (2017). Tick-borne emerging infections: Ehrlichiosis and anaplasmosis. Clinics in laboratory medicine, 37(2), 317-340.

Kazimírová, M., Thangamani, S., Bartíková, P., Hermance, M., Holíková, V., Štibrániová, I., \& Nuttall, P. A. (2017). Tick-borne viruses and biological processes at the tick-host-virus interface. Frontiers in cellular and infection microbiology, 7, 339 . 
Mansfield, K. L., Jizhou, L., Phipps, L. P., \& Johnson, N. (2017). Emerging tick-borne viruses in the twenty-first century. Frontiers in cellular and infection microbiology, 7, 298.

Ogden, N. H., \& Lindsay, L. R. (2016). Effects of climate and climate change on vectors and vectorborne diseases: Ticks are different. Trends in parasitology, 32(8), 646-656.

Ostfeld, R. S., \& Brunner, J. L. (2015). Climate change and Ixodes tick-borne diseases of humans. Philosophical Transactions of the Royal Society B: Biological Sciences, 370(1665), 20140051.

Pfäffle, M., Littwin, N., Muders, S. V., \& Petney, T. N. (2013). The ecology of tick-borne diseases. International Journal for Parasitology, 43(12-13), 1059-1077.

Shabdarbaeva, G. S., Akhmetova, G. D., Turganbaeva, G. E., \& Balgimbaeva, A. I. (2012). Prakticheskoe obuchenie po parazitologii (Uchebnoe posobie po arakhnoentomologii) [Practical training in parasitology (Textbook on arachnoentomology)]. "S-Print", Almaty. https://expobooks.ru/category/book?id=12204

Shabdarbaeva, G. S., Balgimbaeva, A. I., Ibazhanova, A. S., Turganbaeva, G. E., Myrzhieva, A. B., \& Kenzhebekova, Z. Z. (2019a). Osobennosti epizootologii kleshchei-perenoschikov piroplazmoza sobak [Features of the epizootology of ticks carriers of dog pyroplasmosis]. Evrazijskoe Nauchnoe Ob'edinenie [Eurasian Scientific Association], 2-2 (48): 122-125. ISSN: 2411-1899. https://esa-conference.ru/wpcontent/uploads/files/pdf/Ibazhanova-AsemSerikovna.pdf

Shabdarbaeva, G. S., Balgimbaeva, A. I., Ibazhanova, A. S., Turganbaeva, G. E., Myrzhieva, A., Kenzhebekova, Z. Z., \& Shmanov, G. S. (2019b). Issledovanie iksodovykh kleshchei na nalichie teilerii [The study of ixodid ticks for the presence of teileria]. Aktualnye voprosy obrazovaniya i nauki. Vestnik nauchnykh konferentsii [Current issues of education and science. Bulletin of scientific conferences], 2-3 (42): 108-116. ISSN: 2412-8988. https://ukonf.com/doc/cn.2019.02.03.pdf

Shabdarbaeva, G. S., Khusainov, D. M., Dyusembaev, S. T., Myrzhieva, A. B., Ikimbaeva, N. A., Akhmetsadykov, N. N., Berkinbai, O., Ibazhanova, A. S., \& Balgimbaeva, A. I. (2018). Utility model patent No. 3346 - Insektoakaritsidnoe sredstvo dlya mlekopitayushchego [Insecticidal and acaricidal agent for mammals].

Šimo, L., Kazimirova, M., Richardson, J., \& Bonnet, S. I. (2017). The essential role of tick salivary glands and saliva in tick feeding and pathogen transmission. Frontiers in cellular and infection microbiology, 7, 281.
Skosyrskikh, L. N., \& Stolbova, O. A. (2017). Insektoakaritsidnye preparaty dlya veterinarnogo primeneniya [Insectoacaricidal agents for veterinary use]. Mezhdunarodnyi nauchno-issledovatelskii zhurnal [International Research Journal], 12-4(66), 52-56. https://doi.org/10.23670/IRJ.2017.66.011

Smirnov, A. A. (2002). "Dana" composition to treat arachnoentomosis. Patent of the Russian Federation RU 2181243 S1, IPC A01N25/02, A01N35/04, A01N43/50.

https://patentimages.storage.googleapis.com/11/75/0 7/f1cbef9db91e5f/RU2181243C1.pdf

Turganbayeva, G. E., Shabdarbayeva, G. S., Khussainov, D. M., Ibazhanova, A. S., Balgimbaeva, A. I., \& Myrzhieva, A. B. (2018). Distribution and Species Composition of Iksodid Mites in the South of Kazakhstan. In: International Conference, April 910, Deira, Dubai, UAE.

Turganbaeva, G. E., Khusainov, D. M., \& Shabdarbaeva, G. S. (2016a). Effektivnost akaritsidnykh preparatov na osnove prirodnykh biologicheski aktivnykh veshchestv protiv iksodovykh kleshchei $\mathrm{v}$ laboratornykh usloviyakh [The effectiveness of acaricidal agents based on natural biologically active substances against ticks in laboratory conditions]. In: Materialy Mezhdunarodnoi nauchnoprakticheskoi konferentsii "Veterinariya v XXI veke: problemy, metody, resheniya", posvyashchennoi 100-letiyu so dnya rozhdeniya professora Kadyrova Nurgali Tasilovicha [Materials of the International Scientific and Practical Conference "Veterinary Medicine in the 21st Century: Problems, Methods and Solutions" dedicated to the centenary of the birth of Professor N.T. Kadyrov], Kazakh Agrotechnical University, Astana, pp: 196-199.

Turganbaeva, G. E., Shabdarbaeva, G. S., Akhmetsadykov, N. N., Kozhakov, K. K., \& Akhmetzhanova, M. N. (2016b). Stepen zarazhennosti piroplazmidami iksodovykh kleshchei v YuzhnoKazakhstanskoi i Almatinskoi oblastyakh Respubliki Kazakhstan [The prevalence of pyroplasmids infection in ixodid ticks in the South Kazakhstan and Almaty regions of the Republic of Kazakhstan]. Izvestiya natsionalnoi akademii Respubliki Kazakhstan. Seriya agrarnykh nauk [Bulletin of the National Academy of the Republic of Kazakhstan. Agricultural sciences series], 6(36), 48-56. 